\title{
Themes of Reflective Thinking as a Predictor of Physical Education and Sport Pre-Service Teachers' the Entrepreneurial Characteristics
}

\author{
Sadık Adatepe ${ }^{1}$, Murat Kul ${ }^{2}$ \\ ${ }^{1}$ IMKB Sakarya Mesleki ve Teknik Anadolu Lisesi, Sakarya, Turkey \\ ${ }^{2}$ School of Physical Education and Sport, Bartin University, Bartin, Turkey \\ Correspondence: Murat Kul, School of Physical Education and Sport, Bartin University, Bartin, Turkey.
}

Received: August 1, 2018

doi:10.11114/jets.v6i10.3487

Online Published: August 22, 2018

Accepted: August 19, 2018

11114/jets.v6i10.3487

\begin{abstract}
Today, entrepreneurship has gained great importance, especially with the transition from industrial society to information society. Therefore, in order to ensure economic and social development of societies, entrepreneurship must comprehensively be supported, encouraged and entrepreneurship education has to be provided. Many similar qualities and skills among individuals having reflective thinking abilities and entrepreneurial individuals arise when reflective thinking, one of the higher-level thinking skills, is defined as the cognitive inquiry that will lead the individual to produce new knowledge and develop alternative ways. The purpose of this research is to identify whether physical education and sports teachers' reflective thinking themes predict entrepreneurial characteristics. Research is designed in accordance with the relational screening model. Semerci (2007), "Reflective Thinking Tendency Scale" and Yilmaz and Sunbul (2009), "Entrepreneurship Scale for University Students" were used as data collection tool. Multilevel regression analysis was benefitted in the analyze of the data. As a result of this research, it is determined that effective and interrogated teaching sub-dimension was the most independent variable contributing to the entrepreneurial characteristics of physical education and sports pre-service teachers and this was followed by continuous and intentional thinking, responsibility of teaching and science and looking professional sub-dimensions. It has also been determined that sub-dimensions such as open-mindedness, foresighted and sincere and researcher do not make a meaningful contribution to the prediction of entrepreneurial characteristics. Based on these results, it can be said that a pre-service teacher with high entrepreneurial characteristics will have higher reflective thinking tendencies. Besides, it is also possible to analyze how thinking skills such as critical thinking, creative thinking, problem solving and supra-cognitive thinking predict entrepreneurial characteristics.
\end{abstract}

Keywords: reflective thinking, entrepreneurship, physical education and sport pre-service teachers

\section{Introduction}

In terms of the power to build the world; education is a concept with a top-level importance. In every field, education emerges as a universal and national issue. Among these processes, the first step is educators and those who receive education. Teachers have an important role in the development and change of many characteristics, such as skills, talents and qualities of individuals.

The teachers of the information age should be individuals who are both able to produce, use, present and manage information and able to see and evaluate the gaps in their schools, take risks, be self-confident, innovator, independent and having top-level entrepreneurial values (Argon and Selvi,2013). Peltonen (2008), on the other hand, emphasizes how important it is for teachers to be more entrepreneurial if we want entrepreneurship to develop among the students. In recent years, curriculums have begun to include teaching processes that support students' entrepreneurial characteristics at an early age (Deveci\&Aydın, 2017). Successful practical transfer of entrepreneurial skills in the classroom is linked to the fact that the teachers have learnt about entrepreneurship in their undergraduate education (European Commission, 2013). It aims to provide students with practical skills such as problem solving, critical thinking and communication in their undergraduate programs in order to ensure them reaching to a level to establish their own businesses after graduation (Beca, 2007).

According to Semerci (1999), developing and changing world conditions demand thinking individuals who are able to present their existence in a strong manner. Those who are able to think, and therefore able to use their top-level mental 
abilities, will be a more successful and will be able to survive in the future. For this reason, he emphasizes the importance of education through saying "It has been making itself felt as a necessity today and, in the future. He points out that in order this to be successful, multi-directional skill capabilities and the qualification of the educators have to be improved. In transferring learned skills to students, the reflection skills of the educator are a factor that increases the quality of education and the quality of learning. According to Dewey, a reflective thinking teacher constantly questions his/her aims, observes his/her practices and their results, and thinks about each student for either for a short or long time (Moallem, 1997). In addition to this, it is necessary for a teacher who wants to improve his/her teacher competencies should make efforts for change and continuous improvement through self-evaluation, should be open to new knowledge and ideas and should develop himself/herself and his/her institution (MEB, ÖMGY, 2006, 1). At this point, pre-service teachers' reflective thinking tendencies and entrepreneurial skills are important. The relationship between reflective thinking tendencies and entrepreneurship properties of educators in both education activities and business world is a matter which worth investigating in each faculty and each department.

According to Yildiz $(2018,16)$, many innovations and the substitution of various production factors such as human muscle strength and unskilled human resource, and replacement by technology of previously manual tasks cause contraction of public and private sector employment. In this point, entrepreneurship becomes an increasingly important subject for university students. This career related paradigm shift could contribute to young adults' entrepreneurial propensity. As in many other sectors, entrepreneurial intentions of sport students pose a significant potential for individual and societal development.

Therefore, it can be said that; in the process of teacher education, it is necessary to determine the variables that will activate the entrepreneurial characteristics of physical education and sport pre-service teachers. In this direction; the purpose of the research is to identify how physical education and sports teachers' reflective thinking sub-dimensions predict entrepreneurial characteristics. Main problem statement is generated as "Do reflective thinking sub-dimensions of physical education and sports pre-service teachers' predict their entrepreneurial characteristics?" The sub-problems generated in accordance with the problem statement are as follows:

- Which of the reflective thinking sub-dimensions predict entrepreneurial characteristics?

- Which reflective thinking sub-dimension contributes the prediction of entrepreneurial characteristics the most?

\section{Method}

Since a large sample mass was aimed to be reached in the research, indirect screening method was used (Mathiyazhagan and Nandan, 2010). "Relational screening model" was preferred to analyze the relations between the variables. Among the variables taking part in the model; entrepreneurial characteristics were embraced as dependent variable, and reflective thinking themes (continuous and intentional thinking, open-mindedness, effective and interrogated teaching, responsibility of teaching and science, researcher, foresighted and sincere, looking professional) as predictor (independent) variable.

\subsection{Study Group}

The population of this research consists of a total of 240 students studying in the 1st, 2nd, 3rd and 4th classes of School of Physical Education and Sports Physical Education and Sports Teaching Department of Bartin University in the fall semester of 2017-2018 (Teaching department only provides formal education). Since the entire population was reached, no sampling was done. Among the 240 Physical Education and Sports pre-service teacher, 140 were male and 100 were female.

\subsection{Data Collecting Tools}

The "Entrepreneurship Scale for University Students" developed by Yilmaz and Sunbul (2009) and the "Reflective Thinking Tendency Scale" (YANDE) developed by Semerci (2007) were used to collect research data. Besides, "Personal Information Form" for determination of variables such as gender, department, class etc. of the participants are specified as Section 1 in the introduction section of the scales.

The measurement tool named as "Reflective Thinking Tendency Scale" (YANDE) which is developed by Semerci (2007) to determine the reflective thinking tendencies of pre-service teachers involves a total of 35 articles. Articles were scored between 1 and 5 . The options are as "don't agree, mainly disagree, partially agree, mainly agree, completely agree". The Cronbach Alpha reliability coefficient was found 0.933 for the scale in general; and in the sub-dimensions, it was found as; 0.756 for continuous and intentional thinking, 0.835 for open-mindedness, 0.917 for effective and interrogated teaching, 0.745 for responsibility of teaching and science, 0.801 for researcher, 0.813 for being foresighted and sincere and 0.732 for looking professional.

The "Entrepreneurship Scale for University Students" developed by Yilmaz and Sunbul (2009) was used to determine the entrepreneurial characteristics of the pre-service teachers. Scale comprises 36 articles in total. This scale was a 
5-point Likert-type scale and five options were organized from "Very frequent" (5) to "Never" (1). In the scale; it was stated that the higher the score, the more dominant the entrepreneurial characteristics. The reliability of the scale was ensured by the Cronbach Alpha reliability coefficient and Test-Retest method. Cronbach alpha was found 0.930 .

\subsection{Data Analysis}

A multilevel regression analysis was used in the analysis of the data obtained from the research. This analysis is based on inclusion of the contributing variables one by one into the analysis in accordance with their contribution rates starting from the independent variable that contributes most to the explanation of the dependent variable (Ferguson and Takane, 1989). Some assumptions need to be met in order to be able to perform multiple regression analysis on the dataset. To meet the assumptions, the Durbin Watson statistic was taken into consideration and this value was found to be 1.884. Approximation of this value to 2 shows us there is no autocorrelation in the model (Toe, 2013). In addition; kurtosis and skewness values of data sets of dependent and independent variables are seen to take values between - 2 and +2 . Kurtosis and skewness values to be between -2 and +2 met the assumption that the data set is normally distributed (George and Mallery, 2003). Thus, multiple regression analysis assumption of the data set was met.

\section{Findings}

For the research, while entrepreneurship was determined as dependent variable, reflective thinking themes (continuous and intentional thinking, open-mindedness, effective and interrogated teaching, responsibility of teaching and science, researcher, foresighted and sincere, looking professional) as predictor (independent) variable.

Table 1. Descriptive statistics of dependent and independent variables

\begin{tabular}{llccccc}
\hline & \multicolumn{1}{c}{ Variables } & N & Mean & Sd & Kurtosis & Skewness \\
\hline $\begin{array}{l}\text { Dependent } \\
\text { variable }\end{array}$ & Entrepreneurship & 240 & 4.20 & 0.415 & -.474 & .400 \\
& & & & & & \\
\hline & Continuous and intentional thinking & 240 & 4.00 & 0.519 & -.241 & -.360 \\
Sub-scales of & Open-mindedness & 240 & 4.47 & 0.650 & -1.488 & 2.30 \\
independent & Effective and interrogated teaching & 240 & 4.71 & 0.587 & -2.180 & -2.250 \\
variable & Responsibility teaching and science & 240 & 4.28 & 0.670 & -.756 & -.383 \\
& Foresighted and sincere & 240 & 4.11 & 0.750 & -.732 & -.321 \\
& Researcher & 240 & 4.19 & 0.817 & -1.239 & 1.682 \\
& Looking professional & 240 & 4.42 & 0.930 & -1.642 & 1.803 \\
\hline
\end{tabular}

In Table 1, descriptive (sample number, total point averages, standard deviation, skewness and kurtosis) values of dependent and independent variables are given.

Table 2. Pearson Correlation Coefficients Between Variables

\begin{tabular}{|c|c|c|c|c|c|c|c|c|}
\hline $\mathrm{N}=240$ & 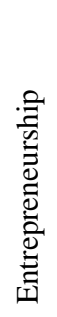 & 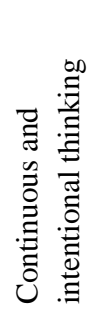 & 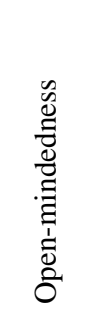 & 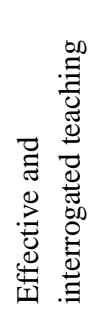 & 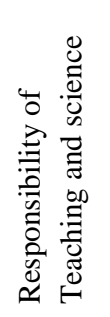 & 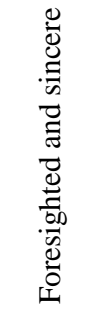 & $\begin{array}{l}\bar{d} \\
\bar{d} \\
\bar{d} \\
0 \\
\simeq\end{array}$ & 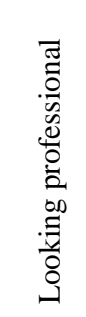 \\
\hline Entrepreneurship & 1 & $.378^{*}$ & $.302 *$ & $.407 *$ & $.397 *$ & $.369^{*}$ & $.317^{*}$ & $.201 *$ \\
\hline
\end{tabular}

As shown in Table 2, correlation coefficients between dependent and independent variables are below .80 ( $\mathrm{p}<.05)$. Besides, the correlation coefficients between the independent variables are also below $.80(\mathrm{p}<.05)$. 
Table 3. Stepwise Multiple Regression Analysis

\begin{tabular}{|c|c|c|c|c|c|c|c|}
\hline Model & Predictors & $\begin{array}{c}\text { Stand. } \\
\beta\end{array}$ & $\mathbf{t}$ & $\mathbf{p}$ & $\mathbf{F}$ & $\mathbf{R}^{2}$ & $\begin{array}{c}\text { Change } \\
\text { of } R^{2}\end{array}$ \\
\hline 1 & Effective and interrogated teaching & .407 & 6.865 & .000 & 47.128 & .166 & .166 \\
\hline \multirow[t]{2}{*}{2} & Effective and interrogated teaching & .307 & 4.936 & .000 & \multirow{2}{*}{17.319} & \multirow{2}{*}{.223} & \multirow{2}{*}{.057} \\
\hline & Continuous and intentional thinking & .259 & 4.162 & .000 & & & \\
\hline \multirow{3}{*}{3} & Effective and interrogated teaching & .232 & 3.249 & .001 & \multirow{3}{*}{4.311} & \multirow{3}{*}{.237} & \multirow{3}{*}{.014} \\
\hline & Continuous and intentional thinking & .212 & 3.221 & .001 & & & \\
\hline & Responsibility of teaching and science & .157 & 2.076 & .039 & & & \\
\hline \multirow{4}{*}{4} & Effective and interrogated teaching & .286 & 3.832 & .001 & \multirow{4}{*}{5.226} & \multirow{4}{*}{.254} & \multirow{4}{*}{.017} \\
\hline & Continuous and intentional thinking & .233 & 3.553 & .001 & & & \\
\hline & $\begin{array}{l}\text { Responsibility teaching responsibility and } \\
\text { science }\end{array}$ & .208 & 2.667 & .008 & & & \\
\hline & Looking professional & -.167 & 2.286 & .023 & & & \\
\hline
\end{tabular}

When the results of the multilevel regression analysis given in Table 3 are examined; in the first stage of the model, it is observed that the predictor which made the most contribution to the entrepreneurial characteristics was effective and interrogated teaching. In this sense, effective and interrogated teaching predictor's contribution to the total variance about the entrepreneurial characteristic was $16.6 \%$, which was found significant statistically $(\mathrm{R} 2=.166, \mathrm{~F}(1,238)=$ $47.128, \mathrm{p}<.05)$. In this sense; correlation between effective and interrogated teaching and entrepreneurship was found .407 which is positive and significant $(\mathrm{p}<.001)$.

In the second stage, in addition to effective and interrogated teaching predictor; it was seen that the predictor which significantly contributes to the entrepreneurial characteristics is continuous and intentional thinking. The additional contribution provided by the continuous and intentional thinking predictor to explain the total variance is $5.7 \%$ and these two predictors explain $22.3 \%$ of the total variance for the entrepreneurial characteristics $\left(\mathrm{R}^{2}=.223, \mathrm{~F}(1,237)\right.$ $=17.319, \mathrm{p}<.05)$. Correlation between continuous and intentional thinking and entrepreneurship was found .378 , which is positive and significant $(\mathrm{p}<.001)$.

In the third stage; in addition to effective and interrogated teaching and continuous and intentional thinking predictors, responsibility of teaching and science predictor was also included into the model. The additional contribution provided by the responsibility of teaching and science predictor to explain the total variance is $1.4 \%$ and these three predictors explain $23.7 \%$ of the total variance for the entrepreneurial characteristics $\left(R^{2}=.237, F(1,236)=4.311, p<.05\right)$. Correlation between responsibility of teaching and science and entrepreneurship was found 397, which is positive and significant $(\mathrm{p}<.001)$.

In the forth stage; in addition to effective and interrogated teaching, continuous and intentional thinking and responsibility of teaching and science predictors, looking professional predictor was included into the model. The additional contribution provided by the looking professional predictor to the model is $1.7 \%$ and these four predictors explain $25.4 \%$ of the total variance for the entrepreneurial characteristics $\left(\mathrm{R}^{2}=.254, \mathrm{~F}(1,235)=5.226, \mathrm{p}<.05\right)$. Correlation coefficient between looking professional and entrepreneurship was found 397, which is positive and significant $(\mathrm{p}<.001)$.

Consequently, it was seen that; effective and interrogated teaching, continuous and intentional thinking, responsibility of teaching and science and looking professional predictors explain $25.4 \%$ of the total variance for entrepreneurial characteristic. On the other hand; it was seen that sub dimensions such as open-mindedness, foresighted and sincere and investigative do not provide statistically significant contribution to the total variance for entrepreneurship.

\section{Discussion, Conclusion and Suggestions}

In this research; it was tried to determine whether reflective themes such as continuous and intentional thinking, open-mindlessness, effective and interrogated teaching, responsibility of teaching and science, to be investigative, foresighted and sincere and looking professional are significant predictor of physical education and sports pre-service teachers' entrepreneurial characteristics. In the light of the findings obtained in this research; it was determined that the best theme that predicts the entrepreneurial characteristics is the effective and interrogated teaching. Thus; it was identified that there is a positive and intermediate relation between effective and interrogated teaching and entrepreneurship. In addition to effective and interrogated teaching theme, other variables that predict the most are found as; continuous and intentional thinking, responsibility of teaching and science and looking professional themes. On the contrary, it has been understood that open-mindedness, foresighted and sincere and to be investigative themes are not significant predictors of physical education and sports pre-service teachers' entrepreneurial characteristics. In the literature, no compatible and incompatible results with regards to predictive variables was found to support these results. 
As a result, it can be said that a large part of the reflective thinking tendency themes are significant predictive variable on entrepreneurship. In the literature, various studies examining the relationship between several variables between reflective thinking tendencies and entrepreneurship to be such as to support the relationship between reflective thinking and entrepreneurship.

There are many researches in the literature about the entrepreneurship characteristics of university students and their reflective thinking tendencies. Reflective thinking and entrepreneurship tendencies of the pre-service teachers are examined in some studies such as; Yanpar and Duban (2010) "Teacher candidates' reflective thinking tendencies and opinions about reflective teacher characteristics", Alkan and Gozel (2012) "). The pre-service primary education teachers' views about reflective thinking skills Pamukkale University. Denizli",Hasirci and Sadik (2011) "Examining the reflective thinking tendencies of primary school", Atalay \& Karahan (2016) "An evaluation of reflective thinking tendencies of Turkish teacher candidates", Aksoy \& Yalcinsoy (2017) "A Research on Entrepreneurial Tendencies of University Students", Pan and Akay (2015) "Examination of entrepreneurship levels of education faculty students in terms of various variables", Akyurek (2013), "The evaluation of elementary school teachers' opinions on the ability to entrepreneurship", Yildiz and Kapu (2012) "The relationship between individual values of university students and entrepreneurial tendencies: A Research in Kafkas University", Kilic, Keklik and Calis, (2012) "A research on the entrepreneurship tendencies of university students:Bandirma Business School" , Kostekci (2015) "Examining the Relationship Between Entrepreneurship Characteristics and Reflective Thinking Levels of Pre-service Teachers" , Akhtar, Keith and Riaz (2009) "Entrepreneurial Inclinations of Prospective Teachers", Adatepe (2018) "Examining Entrepreneurship Characteristics and Reflective Thinking Levels of Pre -service Teachers at Physical Education and Sports School" and Ozturk (2018) "Examining the relationship between entrepreneurship characteristics and reflective thinking levels of pre-service teachers: Sakarya University example".

The contribution of effective and interrogated teaching, continuous and intentional thinking, responsibility of teaching and science and looking professional themes, which are found to be significant predictors in explanation of entrepreneurial characteristics, on total variance was found $25.4 \%$. Although this percentage seem low, these individuals, who are considered potential entrepreneurial and reflective pre-service teachers, may be involved in educational processes to develop these areas and therefore, such educational processes may play an important role in improving their entrepreneurial characteristics. On the other hand; whether other thinking skills which are emphasized in teaching curricula such as critical thinking, creative thinking, problem solving, and supra-cognitive thinking types predict entrepreneurial characteristics may be examined. In addition, experimental research to examine the effects of reflective thinking skills on entrepreneurial characteristics can be conducted in different areas of teaching, such as in coaching education, sports management and recreation education, as well as in other universities and faculties.

\section{References}

Adatepe, S. (2018). Examining Entrepreneurship Characteristics and Reflective Thinking Levels of Pre -service Teachers at Physical Education and Sports School. Master's thesis. Bartin University. Institute of Educational Sciences.Bartin

Akhtar, A., Keith, J. T., \& Riaz, H. T. (2009). Entrepreneurial Inclinations of Prospective Teachers. New Horizons in Education, 56(2).

Aksoy, C., \& Yalcinsoy, A. (2017). A Research on Entrepreneurial Tendencies of University Students. Journal of Business Research - Turk. 9/4 (2017), 341-359. https://doi.org/10.20491/isarder.2017.335

Akyurek, Ç. (2013). The evaluation of elementary school teachers'opinions on the ability to entrepreneurship. Master's thesis. Canakkale Onsekiz Mart University. Canakkale.

Alkan, V., \& Gozel, E. (2012). The pre-service primary education teachers' views about reflective thinking skills Pamukkale University. Denizli. e-Journal of New World Sciences Academy. NWSA-Education Sciences, 1C0568, $8(1), 1-12$.

Argon, T., \& Selvi, Ç. (2013). The relationship between the values of entrepreneurship and the levels of social support perceived by primary school teachers. International Journal of Social Science, 6(1), 179-206. https://doi.org/10.9761/jasss_452

Atalay, T., \& Karahan, B. (2016). An evaluation of reflective thinking tendencies of Turkish teacher candidates. IJTET, $1(2)$.

Beca, J. (2007). The need for improvement in innovativeness development and entrepreneurship training in high school and university science education. T-Space at The University of Toronto Libraries, University of Toronto Mississauga. Retrieved July 10, 2018, from https://tspace.library.utoronto.ca/handle/1807/10112

Deveci, İ., \& Aydin, F. (2017). Multiple Intelligence as a Predictor of the Entrepreneurial Characteristics of 
Prospective Science Teachers. Inonu University Journal of the education Faculty, 18(3).

European Commission, (2013). Entrepreneurship Education: A Guide for Educators. June 2013.Entrepreneurship and Social Economy Unit. European Union, 2013, Bruxelles.

Ferguson, G. A., \& Takane, Y. (1989). Statistical analysis in psychology and education, USA: Me Graw Hill Book.

George, D., \& Mallery, P. (2003). SPSS for Windows step by step: A simple guide and reference, 4th edition, Boston: Allyn \& Bacon.

Hasirci, Ö. K., \& Sadik, F. (2011). Examining the reflective thinking tendencies of primary school teachers'. Cukurova University, Journal of Institute of Social Sciences, 20(2).

Kilic, R., Keklik, B., \& Calis, N. (2012). A research on the entrepreneurship tendencies of university students: Bandirma Business School. Suleyman Demirel University the Journal of Faculty of Economics and Administrative Sciences, 17(2).

Kostekci, E. (2016). Examining the Relationship Between Entrepreneurship Characteristics and Reflective Thinking Levels of Pre-service Teachers. Master's thesis. Bartin University. Institute of Educational sciences. Bartin.

Mathiyazhagan, T., \& Nandan, D. (2010). Survey research method. Media Mimansa, 4(1), 34-45.

MEB (2006). General Qualifications of Teaching Profession. Ministry of Naitonal Education General Directorate of Teacher Training and Education. Ankara.

Moallem, M. (1997). The content and nature of reflective thinking: A case of an expert middle school teacher. The Clearing House, 70(3), 143-151. https://doi.org/10.1080/00098655.1997.10543914

Ozturk, M. (2018). Examining the relationship between entrepreneurship characteristics and reflective thinking levels of pre-service teachers: Sakarya University example. Master's thesis. Bartin University. Institute of Educational sciences. Bartin.

Pan, V. L., \& Akay, C. (2015). Examination of entrepreneurship levels of education faculty students in terms of various variables. E-Journal of New World Sciences Academy. Education Sciences, 10(2). https://doi.org/10.12739/NWSA.2015.10.2.1C0637

Peltonen, K. (2008). Can learning in teams help teacher to become more entrepreneurial? The interplay between efficacy perceptions and team support. LTA, 3, 297-324.

Semerci, Ç. (2007). Developing A Reflective Thinking Tendency Scale for Teachers and Student Teachers. Educational Sciences: Theory \& Practice, 7(3). September 2007. 1351-1377

Semerci, N. (1999). The function of a teacher: developing of thinking. Firat University Journal of Social Science, 9(1).

Teo, T. (2013). Handbook of quantitative methods for educational research. (Ed.), Rotterdam: Sense Publishers. https://doi.org/10.1007/978-94-6209-404-8

Yanpar, Y. T., \& Duban, N. (2010). Teacher candidates' reflective thinking tendencies and opinions about reflective teacher characteristics. Cukurova University The Journal of Institute of Social Sciences, 19(2).

Yildiz, K. (2018). The effect of career decisions on entrepreneurial intention levels of university students studying sport sciences. Journal of Education and Training Studies, 6(4a). https://doi.org/10.11114/jets.v6i4a.3112

Yildiz, S., \& Kapu, S. (2012). The relationship between individual values of university students and entrepreneurial tendencies: A Research in Kafkas University. Kafkas University Journal of The Economics and Administrative Sciences, 3(3).

Yilmaz, E., \& Sunbul, A. M. (2009). Developing scale of university students entrepreneurship. Selcuk University the Journal of Institute of Social Sciences, 21, 195-203.

Note: This study was produced from the master's thesis completed by Sadik Adatepe under the supervision of Ass.Prof.Dr. Murat Kul.

\section{Copyrights}

Copyright for this article is retained by the author(s), with first publication rights granted to the journal.

This is an open-access article distributed under the terms and conditions of the Creative Commons Attribution license which permits unrestricted use, distribution, and reproduction in any medium, provided the original work is properly cited. 